\title{
Estimation of Stature and Age from Head Dimensions in Indian Population
}

\author{
Estimación de la Estatura y Edad a Partir de Dimensiones de la Cabeza en Población India
}

Rajani Singh

SINGH, R. Estimation of stature and age from head dimensions in indian population. Int. J. Morphol., 31(4):1185-1190, 2013.

SUMMARY: Body segments exhibit consistent ratios with stature, age, gender and race. Thus prediction of stature from cranial remains is vital in establishing the identity of an unknown individual in natural calamities and archaeological exploration where entire body skeleton is not available. Little is known about the cranial dimensions in Indian population. Hence the study was carried out to predict stature, age and sex for solving medico-legal problems, anthropological complexities and archaeological investigations. Undergraduate students in the age group of 1726 years of CSM Medical University, UP, India were selected as subjects because of easy access. Cranial dimensions of the subjects were measured by spreading calliper and Todd' head spanner. Heights of subjects were measured by standing height measuring instrument in similar anatomical position and at fixed time to avoid diurnal variation. The correlation and regression analyses and statistical analyses carried out here is most important to anthropologists and forensic science experts to facilitate them to solve complicated medico-legal problems.

KEY WORDS: Forensic science; Height; Glabella; Inion; Spreading calliper; Head length.

\section{INTRODUCTION}

Reconstruction of stature from various bones of the human skeleton has been achieved by many scientists with varying degree of accuracy (Krishan, 2007). Establishment of alternative methodologies for personal height estimation is essential for a number of reasons. Firstly, in instances where height estimates needed to be made from fragments of bones in archaeological procedures or in forensic science after mass disasters or genocide (Krishan, 2007). Secondly, estimates of pharmacokinetic parameters and evaluation status rely on accurate measurement of not only body weight but also height. In clinical practice, population height, and age specific data on cranial dimensions gives an indication of growth and development of an individual and also any abnormalities of cranial size and shape (Harper et al., 1984). This information is of paramount importance to anthropologists to find racial differences, forensic science experts to solve medico-legal problems when only parts of deceased are available and archaeologists to carry out archaeological procedures and may facilitate the process of sex determination.

Although a wide variety of long bones have been employed for stature estimations only few studies have utilized the cranial dimensions in this regard (Krishan, 2007; Jadav \& Shah, 2004; Sarangi et al., 1981). Cranial dimensions have been shown to be a reliable means in predicting the stature in Italians (Introna et al., 1993), Japanese (Chiba \& Terazawa, 1998), and South Africans (Ryan \& Bidmos, 2007). In light of these studies, statistical analyses to help to estimate the stature appear to be significant, potential and of immense practical utility to forensic science experts, anthropologists, archaeologists and demographers. Therefore, an attempt has been made to carry out detailed statistical analyses to estimate stature from cranial dimensions in this study for Indian population.

\section{MATERIAL AND METHOD}

The study was conducted on 208 medical students (148 males and 61 females) in CSM Medical University, UP, India. The subjects were apparently healthy without any craniofacial deformity. They were from different parts of India belonging to different socio-economic status. The age of the subjects ranged from 17-26 years.

The height of the individual was measured between vertex and the floor with the subject standing erect and in anatomical position using standing height measuring instrument. Height was measured to the accuracy of $0.1 \mathrm{~cm}$. 
Following linear dimensions of the head were measured as defined by Williams et al. (2000).

Maximum head length which is distance between the most prominent point on the frontal bone above the root of the nose (glabella) and the most prominent portion of the occipital bone (inion) was measured by placing the anterior calliper tip on glabella while allowing the posterior calliper tip to slide inferiorly along the median plane of the occipital bone until the maximum length was reached.

Maximum head breadth (Maximum biparietal diameter) which is the maximum distance between the most lateral points on the parietal bones was measured by allowing both tips of the spreading calliper to slide down along the lateral aspect of the parietal bones until the maximum width was recorded. Head length and head breadth was measured using spreading calliper capable of measuring to the nearest $0.01 \mathrm{~mm}$.

Head height was measured between the external acoustic meatus and the highest point of the vertex on both sides using the Todd's head spanner.

All the measurements were taken at fixed time between 14:00-16:30 PM to eliminate discrepancies due to diurnal variation. All the measurements were taken by the same person and repeated thrice and the mean was taken.

The degree of sexual divergences in head dimensions was calculated as follows: The index of sexual dimorphism= male mean- female mean/male mean x100 (Hwang et al., 1995).

Range, mean, standard deviation and correlation coefficient of age, height, head length, head breadth and head height were statistically analysed. Correlation coefficient and regression lines for predicting age and height from head dimensions were computed.

\section{RESULTS}

Statistical analyses of age, height, head length, head breadth and head height in terms of mean and Standard Deviation for combined (Male + Female), males and females separately has been presented in Table I. Means of height, head length, head breadth and head height for combined (male+female), males and females has been depicted in Table II. The correlation coefficient between age-height, head length, head breadth and head height were calculated in the present study as tabulated in Table III. The correlation coefficient between height-head length, head breadth and head height was also computed for the subject as shown in Table III.

The index of sexual dimorphism in head length, breadth and height were $16.3 \%, 8.4 \%$ and $0.9 \%$ respectively. Linear regression analyses were performed for estimation of age and height using head length, head breadth and head height as an independent variables.

Regression lines for estimating age and height in both male and female (combined), males and females.

\section{Estimation of Age from height, and head dimensions.} General equation for regression line is $\mathrm{Y}-\mathrm{Y}=\mathrm{byx}(\mathrm{X}-\mathrm{X})$.

\section{(1) Regression lines for combined ( male+female).}

(a) $Y^{\text {age }}=\operatorname{byx}\left\{X^{\mathrm{HT}}-\left(\mathrm{X}^{\mathrm{HT}} \pm \mathrm{SD}\right)\right\}+\left(\mathrm{Y}^{\mathrm{age}} \pm \mathrm{SD}\right), \mathrm{X}^{\mathrm{HT}}=$ Mean height, $\mathrm{Y}^{\text {age }}=$ Mean age

$\mathrm{Y}^{\text {age }}=0.457\left\{\mathrm{X}^{\mathrm{HT}}-(164.24 \pm 8.66)\right\}+20.95 \pm 1.84, \mathrm{X}^{\mathrm{HT}}=$ Height of unknown, Slope $=0.457$

(b) $\mathrm{Y}^{\mathrm{age}}=\operatorname{byx}\left\{\mathrm{X}^{\mathrm{HL}}-\left(\mathrm{X}^{\mathrm{HL}} \pm \mathrm{SD}\right)\right\}+\left(\mathrm{Y}^{\mathrm{age}} \pm \mathrm{SD}\right), \mathrm{X}^{\mathrm{HL}}=$ Mean head length, $\mathrm{Y}^{\text {age }}=$ Mean age

$\mathrm{Y}^{\mathrm{age}}=3.745\left\{\mathrm{X}^{\mathrm{HL}}-(16.67 \pm 0.84)\right\}+20.95 \pm 1.84, \mathrm{X}^{\mathrm{HL}}=$ Head length, Slope $=3.745$

(c) $\mathrm{Y}^{\text {age }}=\operatorname{byx}\left\{\mathrm{X}^{\mathrm{HB}}-\left(\mathrm{X}^{\mathrm{HB}} \pm \mathrm{SD}\right)\right\}+\left(\mathrm{Y}^{\mathrm{age}} \pm \mathrm{SD}\right), \mathrm{X}^{\mathrm{HB}}=$ Mean head breadth, $\mathrm{Y}^{\text {age }}=$ Mean age

$Y^{\text {age }}=-2.397\left\{X^{\text {HB }}-(12.95 \pm 0.67)+20.95 \pm 1.84, X^{\mathrm{HB}}=\right.$ Head breadth, Slope $=2.397$

(d) $Y^{\text {age }}=$ byx $\left\{X^{\mathrm{HH}}-\left(\mathrm{X}^{\mathrm{HH}} \pm \mathrm{SD}\right)\right\}+\left(\mathrm{Y}^{\text {age }} \pm \mathrm{SD}\right), \mathrm{X}^{\mathrm{HH}}=$ Mean head height, $\mathrm{Y}^{\text {age }}=$ Mean age

$Y^{\operatorname{age}}=-1.571\left\{X^{\mathrm{HH}}-(10.12 \pm 0.93)\right\}+20.95 \pm 1.87, X^{\mathrm{HL}}=$ Head height, Slope $=1.571$

(2) Regression lines for male.

(a) $\mathrm{Y}^{\text {age }}=\operatorname{byx}\left\{\mathrm{X}^{\mathrm{HT}}-\left(\mathrm{X}^{\mathrm{HT}} \pm \mathrm{SD}\right)\right\}+\left(\mathrm{Y}^{\text {age }} \pm \mathrm{SD}\right), \mathrm{X}^{\mathrm{HT}}=$ Mean height, $\mathrm{Y}^{\mathrm{age}}=$ Mean age

Table I. Range, Mean and Standard Deviation of combined (male+female), Male and Female population.

\begin{tabular}{|c|c|c|c|c|c|c|}
\hline Parameters & $\begin{array}{c}\text { Range } \\
\mathrm{C}\end{array}$ & $\begin{array}{c}\text { Mean } \pm \text { SD } \\
C\end{array}$ & $\begin{array}{c}\text { Range } \\
\text { M }\end{array}$ & $\begin{array}{c}\text { Mean } \pm \text { SD } \\
M\end{array}$ & $\begin{array}{c}\text { Range } \\
\text { FM }\end{array}$ & $\begin{array}{c}\text { Mean } \pm \text { SD } \\
\text { FM }\end{array}$ \\
\hline Age in yrs & $17-26$ & $21 \pm 2$ & $17-26$ & $21 \pm 2$ & $17-23$ & $20 \pm 1$ \\
\hline $\mathrm{HT}$ in $\mathrm{cm}$ & $142.7-193.2$ & $164.2 \pm 8.7$ & $142.7-193.2$ & $167.2 \pm 7.8$ & $144.5-174.4$ & $157.0 \pm 6.0$ \\
\hline $\mathrm{HL}$ in $\mathrm{cm}$ & 14.3-19.2 & $16.7 \pm 0.8$ & $15.2-19.2$ & $17.0 \pm 0.7$ & 14.3-19.2 & $16.0 \pm 0.8$ \\
\hline $\mathrm{HB}$ in $\mathrm{cm}$ & $11.2-15.0$ & $13.0 \pm 0.7$ & $11.4-15.0$ & $13.1 \pm 0.6$ & $11.2-14.1$ & $12.5 \pm 0.6$ \\
\hline $\mathrm{HH}$ in $\mathrm{cm}$ & $8.2-13.4$ & $10.1 \pm 0.9$ & 8.3-13.3 & $10.2 \pm 0.9$ & $8.2-13.4$ & $10.1 \pm 0.9$ \\
\hline
\end{tabular}


Table II. Age versus means of height, head length, head breadth and head height in combined (male+female), male and female popu lation.

\begin{tabular}{lcccccccccccc}
\hline Age in years & \multicolumn{3}{c}{ Mean HT in cm } & \multicolumn{3}{c}{ Mean HL in cm } & \multicolumn{3}{c}{ Mean HB in cm } & \multicolumn{3}{c}{ Mean HH in cm } \\
\hline & C & M & FM & C & M & FM & C & M & FM & C & M & FM \\
17 & 159.9 & 164.3 & 157.7 & 15.9 & 164.3 & 15.8 & 13.0 & 14.1 & 12.5 & 9.5 & 10.2 & 9.1 \\
18 & 162.3 & 167.7 & 154.5 & 16.3 & 167.7 & 15.7 & 13.1 & 13.3 & 12.8 & 10.5 & 10.7 & 10.0 \\
19 & 166.4 & 169.4 & 156.8 & 16.8 & 169.4 & 16.6 & 13.1 & 13.3 & 12.7 & 10.1 & 10.1 & 10.2 \\
20 & 163.6 & 169.4 & 157.4 & 16.6 & 169.4 & 15.9 & 12.9 & 13.3 & 12.5 & 10.1 & 10.4 & 9.8 \\
21 & 164.5 & 168.3 & 157.3 & 16.7 & 168.3 & 16.0 & 12.9 & 13.1 & 12.4 & 10.0 & 10.2 & 9.6 \\
22 & 161.2 & 163.2 & 157.5 & 16.6 & 163.2 & 16.0 & 12.8 & 13.1 & 12.4 & 10.1 & 10.2 & 10.1 \\
23 & 165.1 & 165.6 & 154 & 16.8 & 165.6 & 16.2 & 13.1 & 13.1 & 12.4 & 10.1 & 10.3 & 12.4 \\
24 & 165.6 & 165.6 & & 16.8 & 165.6 & & 12.8 & 12.8 & & 9.5 & 9.5 & 10.4 \\
25 & 167.7 & 168.6 & & 17.1 & 168.6 & & 12.8 & 12.8 & & 10.4 & 10.4 \\
26 & 161.7 & 161.7 & & 16.2 & 161.7 & & 13.3 & 13.3 & & 9.3 & 9.3 & \\
\hline
\end{tabular}

Table III. Correlation coefficients of variables.

\begin{tabular}{llcc}
\hline Coefficient of Correlation/slope & Combined & Male & Female \\
\hline C(Age-HT) /byx & $0.38 / 0.457$ & $-0.35 /-0.395$ & $-0.22 /-0.310$ \\
C(Age-HL) /byx & $0.43 / 3.745$ & $0.004 / 0.037$ & $0.39 / 2.795$ \\
C(Age-HB) /byx & $-0.14 /-2.397$ & $-0.71 /-5.699$ & $-0.67 /-10.135$ \\
$\mathrm{C}($ Age-HH) /byx & $-0.21 /-1.571$ & $-0.59 /-4.298$ & $0.69 / 1.417$ \\
$\mathrm{C}(\mathbf{H T}-\mathbf{H L}) /$ byx & $0.90 / 6.442$ & $0.74 / 5.809$ & $-0.007 /-0.035$ \\
$\mathrm{C}(\mathbf{H T}-\mathbf{H B}) /$ byx & $-0.35 /-4.947$ & $-0.21 /-1.495$ & $-0.31 /-3.29$ \\
$\mathrm{C}(\mathbf{H T}-\mathbf{H H}) /$ byx & $0.41 / 2.531$ & $0.58 / 3.814$ & $-0.76 /-1.116$ \\
\hline
\end{tabular}

$\mathrm{Y}^{\text {age }}=-0.395\left\{\mathrm{X}^{\mathrm{HT}}-(167.17 \pm 7.81)\right\}+21.24 \pm 1.92, \mathrm{X}^{\mathrm{HT}}=$ Height, Slope $=0.395$

(b) $\mathrm{Y}^{\mathrm{age}}=$ byx $\left\{\mathrm{X}^{\mathrm{HL}}-\left(\mathrm{X}^{\mathrm{HL}} \pm \mathrm{SD}\right)\right\}+\left(\mathrm{Y}^{\mathrm{age}} \pm \mathrm{SD}\right), \mathrm{X}^{\mathrm{HL}}=$ Mean head length, $\mathrm{Y}^{\text {age }}=$ Mean age

$\mathrm{Y}^{\mathrm{age}}=0.037\left\{\mathrm{X}^{\mathrm{HL}}-(16.95 \pm 0.71)\right\}+21.24 \pm 1.92, \mathrm{X}^{\mathrm{HL}}=$ Head length, Slope $=0.037$

(c) $\mathrm{Y}^{\text {age }}=$ byx $\left\{\mathrm{X}^{\mathrm{HB}}-\left(\mathrm{X}^{\mathrm{HB}} \pm \mathrm{SD}\right)\right\}+\left(\mathrm{Y}^{\mathrm{age}} \pm \mathrm{SD}\right), \mathrm{X}^{\mathrm{HB}}=$ Mean head breadth, $\mathrm{Y}^{\text {age }}=$ Mean age

$\mathrm{Y}^{\mathrm{age}}=-5.699\left\{\mathrm{X}^{\mathrm{HB}}-(13.13 \pm 0.591)\right\}+21.24 \pm 1.92, \mathrm{X}^{\mathrm{HB}}=\mathrm{Head}$ breadth, Slope $=5.699$

(d) $\mathrm{Y}^{\text {age }}=$ byx $\left\{\mathrm{X}^{\mathrm{HH}}-(\mathrm{XHH} \pm \mathrm{SD})\right\}+\left(\mathrm{Y}^{\text {age }} \pm \mathrm{SD}\right), \mathrm{X}^{\mathrm{HH}}=$ Head height, $\mathrm{Y}^{\text {age }}=$ Mean age

$\mathrm{Y}^{\mathrm{age}}=-4.298\left\{\mathrm{X}^{\mathrm{HH}}-(10.22 \pm 0.93)\right\}+(21.24 \pm 1.92), \mathrm{X}^{\mathrm{HH}}=\mathrm{Head}$ height, Slope $=4.298$

\section{(3) Regression lines for female}

(a) $\mathrm{Y}^{\text {age }}=$ byx $\left\{\mathrm{X}^{\mathrm{HT}}-\left(\mathrm{X}^{\mathrm{HT}} \pm \mathrm{SD}\right)\right\}+\left(\mathrm{Y}^{\text {age }} \pm \mathrm{SD}\right), \mathrm{X}^{\mathrm{HT}}=$ Mean height, $\mathrm{Y}^{\mathrm{age}}=$ Mean age

$\mathrm{Y}^{\text {age }}=-0.310\left\{\mathrm{X}^{\mathrm{HT}}-(157 \pm 6.04)\right\}+20.22 \pm 1.42, \mathrm{X}^{\mathrm{HT}}=$ Height, Slope $=0.310$

(b) $\mathrm{Y}^{\text {age }}=$ byx $\left\{\mathrm{X}^{\mathrm{HL}}-(? \mathrm{XHL} \pm \mathrm{SD})\right\}+\left(\mathrm{Y}^{\mathrm{age}} \pm \mathrm{SD}\right), \mathrm{X}^{\mathrm{HL}}=$ Mean head length, $\mathrm{Y}^{\text {age }}=$ Mean age

$\mathrm{Y}^{\mathrm{age}}=2.795\left\{\mathrm{X}^{\mathrm{HL}}-(15.99 \pm 0.75)\right\}+20.22 \pm 1.42, \mathrm{X}^{\mathrm{HL}}=$ head length, Slope $=2.795$

(c) $\mathrm{Y}^{\text {age }}=$ byx $\left.\left\{\mathrm{X}^{\mathrm{HB}}-\left(\mathrm{X}^{\mathrm{HB}} \pm \mathrm{SD}\right)\right\}+\mathrm{Y}^{\text {age }} \pm \mathrm{SD}\right), \mathrm{X}^{\mathrm{HB}}=$ Mean head breadth, $Y^{\text {age }}=$ Mean age

$Y^{\text {age }}=-10.135\left\{X^{\mathrm{HB}}-(12.49 \pm 0.62)\right\}+20.22 \pm 1.42, \mathrm{X}^{\mathrm{HB}}=$ Head breadth, Slope $=10.135$

(d) $\mathrm{Y}^{\mathrm{age}}=$ byx $\left\{\mathrm{X}^{\mathrm{HH}}-\left(\mathrm{X}^{\mathrm{HH}} \pm \mathrm{SD}\right)\right\}+\left(\mathrm{Y}^{\text {age }} \pm \mathrm{SD}\right), \mathrm{X}^{\mathrm{HH}}=$ Mean head height, $\mathrm{Y}^{\text {age }}=$ Mean age

$\mathrm{Y}^{\mathrm{age}}=1.417\left\{\mathrm{X}^{\mathrm{HH}}-(10.13 \pm 0.86)\right\}+20.22 \pm 1.42, \mathrm{X}^{\mathrm{HH}}=\mathrm{Head}$ height, Slope $=1.417$

\section{Height from head dimensions.}

\section{(1) Regression lines for combined (male+female).}

(a) $\mathrm{Y}^{\mathrm{HT}}=$ byx $\left\{\mathrm{X}^{\mathrm{HL}}-\left(\mathrm{X}^{\mathrm{HL}} \pm \mathrm{SD}\right)\right\}+\left(\mathrm{Y}^{\mathrm{HL}} \pm \mathrm{SD}\right), \mathrm{X}^{\mathrm{HL}}=$ Mean head length, $\mathrm{Y}^{\mathrm{HL}}=$ Mean height

$\mathrm{YHT}=6.442\left\{\mathrm{X}^{\mathrm{HL}}-(16.67 \pm 0.84)\right\}+164.24 \pm 8.66, \mathrm{X}^{\mathrm{HL}}=\mathrm{Head}$ length, Slope $=6.442$

(b) $\mathrm{Y}^{\mathrm{HT}}=$ byx $\left\{\mathrm{X}^{\mathrm{HB}}-\left(\mathrm{X}^{\mathrm{HB}} \pm \mathrm{SD}\right)\right\}+\left(\mathrm{Y}^{\mathrm{HT}} \pm \mathrm{SD}\right), \mathrm{X}^{\mathrm{HB}}=$ Mean head breadth, $\mathrm{Y}^{\mathrm{HT}}=$ Mean height

$\mathrm{YHT}=-4.947\left\{\mathrm{X}^{\mathrm{HB}}-(12.95 \pm 0.67)\right\}+164.24 \pm 8.66, \mathrm{H}^{\mathrm{HB}}=\mathrm{Head}$ breadth, Slope $=-4.947$ 
(c) $\mathrm{Y}^{\mathrm{HT}}=$ byx $\left\{\mathrm{X}^{\mathrm{HH}}-\left(\mathrm{X}^{\mathrm{HH}} \pm \mathrm{SD}\right)\right\}+\left(\mathrm{Y}^{\mathrm{HT}} \pm \mathrm{SD}\right), \mathrm{X}^{\mathrm{HH}}=$ mean head height, $\mathrm{Y}^{\mathrm{HT}}=$ Mean height

$\mathrm{Y}^{\mathrm{HT}}=2.531\left\{\mathrm{X}^{\mathrm{HH}}-(10.12 \pm 0.93)\right\}+164.24 \pm 8.66$

\section{(2) Regression lines for male.}

(a) $\mathrm{Y}^{\mathrm{HT}}=$ byx $\left\{\mathrm{X}^{\mathrm{HL}}-\left(\mathrm{X}^{\mathrm{HL}} \pm \mathrm{SD}\right)\right\}+\left(\mathrm{Y}^{\mathrm{HT}} \pm \mathrm{SD}\right), \mathrm{X}^{\mathrm{HL}}=$ Mean head length, $\mathrm{Y}^{\mathrm{HT}}=$ Mean height

$\mathrm{YHT}=5.809\left\{\mathrm{X}^{\mathrm{HL}}-(16.95 \pm 0.71)\right\}+167.17 \pm 7.81, \mathrm{X}^{\mathrm{HL}}=\mathrm{Head}$ length, Slope $=5.809$

(b) $\mathrm{Y}^{\mathrm{HT}}=$ byx $\left\{\mathrm{X}^{\mathrm{HB}}-\left(\mathrm{X}^{\mathrm{HB}} \pm \mathrm{SD}\right)\right\}+\left(\mathrm{Y}^{\mathrm{HT}} \pm \mathrm{SD}\right), \mathrm{X}^{\mathrm{HB}}=$ Mean head breadth, $\mathrm{Y}^{\mathrm{HT}}=$ Mean height

$\mathrm{Y}^{\mathrm{HT}}=-1.495\left\{\mathrm{X}^{\mathrm{HB}}-(13.13 \pm 0.59)\right\}+167.17 \pm 7.81, \mathrm{X}^{\mathrm{HB}}=$ Head breadth, Slope $=1.495$

(c) $\mathrm{Y}^{\mathrm{HT}}=\operatorname{byx}\left\{\mathrm{X}^{\mathrm{HH}}-\left(\mathrm{X}^{\mathrm{HH}} \pm \mathrm{SD}\right)\right\}+\left(\mathrm{Y}^{\mathrm{HT}} \pm \mathrm{SD}\right), \mathrm{X}^{\mathrm{HH}}=$ Mean head height, $\mathrm{Y}^{\mathrm{HT}}=$ Mean height

$\mathrm{Y}^{\mathrm{HT}}=3.814\left\{\mathrm{X}^{\mathrm{HH}}-(10.22 \pm 0.93)\right\}+167.17 \pm 7.81, \mathrm{X}^{\mathrm{HH}}=$ Head height, Slope $=3.814$

\section{(3) Regression lines for female.}

(a) $\mathrm{Y}^{\mathrm{HT}}=\operatorname{byx}\left\{\mathrm{X}^{\mathrm{HL}}-\left(\mathrm{X}^{\mathrm{HL}} \pm \mathrm{SD}\right)\right\}+\left(\mathrm{Y}^{\mathrm{HT}} \pm \mathrm{SD}\right), \mathrm{X}^{\mathrm{HL}}=$ Mean head length, $\mathrm{Y}^{\mathrm{HT}}=$ Mean height

$\mathrm{Y}^{\mathrm{HT}}=-0.035\left\{\mathrm{X}^{\mathrm{HL}}-(15.99 \pm 0.75)\right\}+157 \pm 6.04, \mathrm{X}^{\mathrm{HL}}=$ Head length, Slope $=-0.035$

(b) $\mathrm{Y}^{\mathrm{HT}}=$ byx $\left\{\mathrm{X}^{\mathrm{HB}}-\left(\mathrm{X}^{\mathrm{HB}} \pm \mathrm{SD}\right)\right\}+\left(\mathrm{Y}^{\mathrm{HT}} \pm \mathrm{SD}\right), \mathrm{X}^{\mathrm{HB}}=$ Mean head breadth, $\mathrm{Y}^{\mathrm{HT}}=$ Mean height

$\mathrm{Y}^{\mathrm{HT}}=-3.29\left\{\mathrm{X}^{\mathrm{HB}}-(12.49 \pm 0.62)\right\}+157 \pm 6.04, \mathrm{X}^{\mathrm{HB}}=$ Head breadth, Slope $=-3.29$

(c) $\mathrm{Y}^{\mathrm{HT}}=$ byx $\left\{\mathrm{X}^{\mathrm{HH}}-\left(\mathrm{X}^{\mathrm{HH}} \pm \mathrm{SD}\right)\right\}+\left(\mathrm{Y}^{\mathrm{HT}} \pm \mathrm{SD}\right), \mathrm{X}^{\mathrm{HH}}=$ Mean head height, $\mathrm{Y}^{\mathrm{HT}}=$ Mean height

$\mathrm{Y}^{\mathrm{HT}}=-1.116\left\{\mathrm{X}^{\mathrm{HH}}-(10.13 \pm 0.86)\right\}+157 \pm 6.04, \mathrm{X}^{\mathrm{HH}}=$ Head height, Slope $=-1.116$

\section{DISCUSSION}

The present study provides valuable new data pertaining to the principal anatomical dimensions of the skull and its correlation with the stature and age in adult Indian population.

Range is the measure of central tendency. Range of height, head length, head breadth and head height in males are 142.7-193.2, 15.2-19.2, 11.1- 15 and 8.3-13.3 respectively. It means height and cranial dimensions on Indian population in age group 17-26 revolve around these measurements. Similarly in females ranges of height, head length, head breadth and head height are 144.5-174.4, 14.319.2, 11.2-14.1 and 8.2-13.4 respectively. It indicates height of females in age group of 17-23 lies within 144.5 to 174.4. Head length, head breadth and head height of all females in 1188 this age group lie in 14.3-19.2, 11.2-14.1 and 8.2-13.4 respectively. Mean is the measure of central tendency. Means of height, head length, head breadth and head height of males are $167.17,16.95,13.13$ and 10.22 respectively. Hence, heights of majority of males lies around 167.17 with standard deviation of 7.81. Similarly head length, head breadth and head height will be $16.95,13.13$ and 10.22 with standard deviation of $0.71,0.59$ and 0.93 respectively in most males of age group of 17-26 of Indian population. Moreover in females mean height is 157.0. Majority of females will have height of 157.0 with standard deviation of 6.04. Means of head length, head breadth and head height are 15.99, 12.49, 12.49 and 10.13 with standard deviation of $0.75,0.62$ and 0.86 . Thus females of age group 17-23 of Indian population will have cranial dimensions nearer to these means.

Very high correlation coefficient of 0.90 between total height-head length is interpreted as the head length and height have strong linear relation which provide an excellent tool to estimate height from head length. Head height bears a moderate correlation of 0.41 with height may be a reasonably good tool for estimating height but not like head length. Correlation between head breadth and height is low with correlation of 0.35 and so it may provide just an idea regarding estimation of height.

Previous studies have shown correlation coefficients of 0.20 (Saxena et al., 1981), 0.53 (Jadav \& Shah) and 0.78 (Krishan, 2008) and 0.72 between cranial length and height whereas in the present study it was 0.90 which is highest as observed in previous studies. Thus variations observed in correlation coefficients may be due to populations of varied geographical areas.

High correlation coefficient of 0.74 in males between height and head length shows that height can be fairly well predicted in males from head length and the same in females is 0.0069 which exhibits almost no correlation between height and head length in females. In females head length cannot be a good tool for estimating height using head length. There is correlation of 0.21 in males and 0.31 in females with respect to height versus head breadth i.e. correlation is very low and low respectively in males and females for these cranial dimensions and thus head breadth cannot be very useful tool for determination of height from head breadth. Considering head height in males $(0.58)$ and females $(0.76)$, correlation is moderate and high respectively. Therefore head height can well be used to predict height with high degree of accuracy in both males and females.

Correlation between height and head length in Indian male (0.74) is higher than their Sri Lankan (0.715) counterparts. In Indian females it is negligible (0.0069) which in Sri 
Lankan female is 0.470 . Similarly correlation coefficient between head breadth and head height in two sexes in Indian and Sri Lankan are 0.21, 0.31 and 0.312 and 0.454 respectively which is lower in Indian as compared to their Sri Lankan counterparts. Furthermore correlation coefficient with respect to head height and stature in Indian male (0.58) and female (0.76) is higher than those of Sri Lankan counterparts which is 0.514 and 0.478 in males and females respectively.

There is no data in literature to compare the correlation coefficients between age-height, age head length, age-head breadth and age- head height. The differences in relation to cranial dimensions observed in males and females may be used in determining sex and may be due to populations of different geographical areas.

Sexual dimorphism is an important component of the morphological variation in biological populations (Williams et al.). The sex divergence in cranial morphometry observed in present study supports the previous observations (Hwang et al.; Dekaban, 1977; Manjunath, 2000; Golalipour et al., 2005). As rate of skeletal maturity in males and females vary during the course of growth and development, there is need for alternative formulae for genders (Williams et al.).

In forensic examinations and anthropological studies, prediction of stature from incomplete and decomposed cranial remains is vital in establishing the identity of an unknown individual. Therefore formulae based on the cranial dimensions provide an alternative stature predictor under such circumstances. Data can be used in conjunction with other anthropological techniques to sex and race determination of unknown individuals.

Variety of factors such as age, race, sex and nutritional status affect development and growth and therefore different normograms are required for different populations (Williams et al.). The present study has documented such norms for cranial dimensions and presented gender specific linear regression lines for stature and age prediction in adult Indian population. Thus population, sex and age specific regression lines will be of immense use in medico-legal, anthropological and archaeological studies.

\section{CONCLUSION}

For male Indian population correlation coefficient with respect to head length (0.74) and head height (0.58) are very high and moderately high and can be used for estimating heights of males with fair degree of accuracy. Similarly in females head height can be used with fair degree of accuracy for determining height but head length is of little importance for estimating height in females. Regression lines provided in the present study are simple, comprehensive, less cumbersome and rapid tool for estimating height of unknown Indian individuals anywhere in the world. Besides this, age of the individual can also be estimated through regression lines using data on cranial dimensions. Thus data provided in the present study will of paramount importance to anthropologists to find racial differences and medicolegally when only parts of deceased or Indian anywhere in the world are available and may be key to sex determination

\section{ACKNOWLEDGEMENTS}

Author is grateful to the head of department, Anatomy to grant permission to carry out the study and also to the students of first year MBBS students for agreeing to carry out measurements on them.

SINGH, R. Estimación de la estatura y edad a partir de dimensiones de la cabeza en población India. Int. J. Morphol., 31(4):1185-1190, 2013.

RESUMEN: Los segmentos corporales presentan proporciones de acuerdo a estatura, edad, sexo y raza. Así, la predicción de medidas de los restos craneales es vital para determinar la identidad de un individuo en desastres naturales, como también, en la investigación arqueológica en los casos cuando no se encuentra disponible el esqueleto completo. Existe escasa información acerca de las dimensiones craneales en la población de la India. El presente estudio se llevó a cabo para predecir la estatura, edad y sexo con el propósito de asistir en la resolución de problemas médico-legales, las complejidades antropológicas y las investigaciones arqueológicas. Como sujetos de estudio fueron seleccionados, debido a su fácil contribución, estudiantes universitarios entre 17 a 26 años de edad de la CSM Medical University, UP, India. Las dimensiones craneales de los sujetos se midieron mediante caliper digital deslizante y llave de Todd. Las alturas de los sujetos fueron tomadas por medición en posición anatómica de pie y en el tiempo fijado para evitar la variación diurna. Los análisis de correlación y regresión además de los análisis estadísticos realizados son importantes para antropólogos y expertos en las ciencias forenses con el propósito de facilitar y resolver complejos problemas médico-legales.

PALABRAS CLAVE: Ciencia forense; Altura; Glabela; Inion; Caliper deslizante; Longitud de la cabeza. 


\section{REFERENCES}

Chiba, M. \& Terazawa, K. Estimation of stature from somatometry of skull. Forensic Sci. Int., 97(2-3):87-92, 1998.

Dekaban, A. S. Tables of cranial and orbital measurements, cranialvolume and derived indexex in males and females from 7 days to 20 years of age. Ann. Neurol., 2(6):485-91, 1977.

Golalipour, M. J.; Jahanshael, M. \& Haidari, K. Estimation of cranial capacity in 17-20 years old in South East of Caspian Sea Border (North of Iran). Int. J. Morphol., 23(4):301-4, 2005.

Harper, C.; Krill, J.; Raven, S. \& Jones, N. Intracranial cavity volumes: A new method and its potential applications. Neuropathol. Appl. Neurobiol., 10(1):25-32, 1984.

Hwang, Y. I.; Lee, K. H.; Choi, B. Y.; Lee, K. S.; Lee, H. Y.; Sir, W. S.; Kim, H. J.; Koh, K. S.; Han, S. H.; Chung, M. S.; et al. Study on the Korean adult cranial capacity. J. Korean Med. Sci., 10(4):239-42, 1995.

Introna, F. Jr.; Di Vella, G. \& Petrachi, S. Determination of height in life using multiple egression of skull parameters. Boll. Soc. Ital. Biol. Sper., 69(3):153-60, 1993.

Jadav, H. R. \& Shah, G. V. Determination of personal height from the length of head in Gujarat Region. J. Anat. Soc. India 53(1):20-1, 2004.

Krishan, K. Anthropometry in Forensic Medicine and Forensic Science-'Forensic Anthropometry'. Internet J. Forensic Sci., 2(1), 2007. Available in: http://ispub.com/IJFS/2/1/10656

Krishan, K. Estimation of stature from cephalo-facial anthropometry in north Indian population. Forensic Sci. Int., 181(1-3):52.e1-6, 2008.

Manjunath, K. Y. Estimation of cranial volume in dissecting room cadavers. J. Anat. Soc. India, 51:168-72, 2000.

Ryan, I. \& Bidmos, M. A. Skeletal height reconstruction from measurements of the skull in indigenous South Africans. Forensic Sci. Int., 167(1):16-21, 2007.

Sarangi, A. K.; Dadhi, B. \& Mishra, K. K. Estimating of stature from adult skull bone. J. Indian Acad. Forensic Med., 182:246, 1981 .

Saxena, S. K.; Jeyasingh, P.; Gupta, A. K. \& Gupta, C. D. The estimation of stature from head-length. J. Anat. Soc. India, 30:78-9, 1981.

Williams, P. L.; Bannister, L. H.; Berry, M. M.; Collins, P.; Dyson, M. \& Dussek, J. E. Gray's Anatomy: The anatomical basis of medicine and surgery. $38^{\text {th }}$ ed. New York, Churchill Livingstone, 2000.

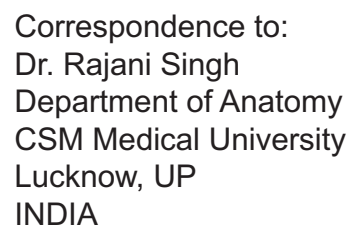

Email: nani_sahayal@rediffmail.com

Received: 06-06-2012

Accepted: 10-08-2013 